\title{
Effect of Lanthanum on Microstructures and Properties of ASTM A216 Steel
}

\author{
A. -Q. Wang, ${ }^{a^{*}}$ M. Li, ${ }^{a}$ D.-Q. Ma, ${ }^{\text {b }}$ Q. $-J$. Wu, and J.-P. Xie ${ }^{\text {a }}$ \\ a School of Materials Science and Engineering, Henan University of Science and Technology, \\ 471023 Luoyang, P.R. China \\ bSchool of Physical Engineering, Zhengzhou University, 450001 Zhengzhou, Henan, P.R. China
}

\begin{abstract}
\| Abstract
In order to satisfy the rudder horn casting standards of the International Association of Classification Societies, the properties of ASTM A216 steel should be improved. Therefore, in this article the rudder horn casting and accompanying specimens were cast moulded by arc furnace smelting, external refining, and modification treatment of the molten steel by lanthanum. The samples were first underwent normalizing treatment at $900{ }^{\circ} \mathrm{C}$ for 10 hours, then air cooled, followed by tempering treatment at $600{ }^{\circ} \mathrm{C}$ for 7 hours and samples were air cooled again. The mechanical properties and microstructures of the samples were measured. The crystallography relationships between lanthanum compounds formed in the molten steel and primary $\delta$-Fe were analysed. The nucleation effect of lanthanum compounds as a heterogeneous nucleation core of primary $\delta$-Fe were calculated and discussed based on two-dimensional mismatch theory. The results indicated that the strip MnS inclusions in ASTM A216 steel became granular rare earth compound inclusions due to La. The refined microstructures were obtained by a synergistic effect of the enhanced condensate depression and the nucleation rate of melt and La compounds as the heterogeneous nucleation caused by La.
\end{abstract}

\section{|| Keywords}

ASTM A216 steel, inclusion, lanthanum, two-dimensional mismatch, grain refinement

\section{Introduction}

With the development of modern marine technology, ASTM A216 steel, as a material of industrial rudder horn casting, should not only have higher hardness, plasticity and toughness, but also pass ultrasonic testing and magnetic particle inspection by the International Association of Classification Societies (IACS). Non-metallic inclusions, as an independent phase in steel casting, could destroy the continuity of the matrix, cause stress concentration and fatigue break, and decrease the toughness. Non-metallic inclusions with different morphologies, distribution, and sizes have different effects on the properties of the steel..$^{1-4}$ The addition of rare earth could clean the molten steels, ${ }^{5-9}$ remove the gas in the molten steel, reduce the amount of phosphorus and sulfur, and improve the morphology, distribution, and size of non-metallic inclusions. Meanwhile, the addition of rare earth could also refine the crystals, prevent the production of dendritic segregation, and increase the mobility of molten steel, so the properties of casting can be enhanced. External refining and vacuum melting etc., are very common in production to improve the quality of shipping casting. Early in a production, without modification, $10 \%$ of rudder horn castings were scraped due to excessive amounts of strip inclusions. In this paper, ASTM A216 steel, as a material of industrial rudder horn casting modified by lanthanum was researched. The effect of La on microstructures and properties of samples and morphologies of inclusions, and the nucleation effects of lanthanum compounds as the non-spontaneous nuclea-

* Corresponding author: Prof. Ai-Qin Wang

e-mail: aiqin_wang888@163.com tion core were discussed. This research could provide the theoretical basis for the application of rare earth La in low carbon steel.

\section{Experimental}

\subsection{Materials and Methods}

\section{Alkaline electric arc furnace initial smelting}

Clean, high quality steel scrap and pig iron were selected as the raw material, and a right amount of bottom ash was used to ensure the residual element content. Charging materials were baked well and carbon powder stayed dry. Compositions of the alloy were controlled within a certain range $\left(0.16 \% \leq w_{\mathrm{C}} \leq 0.24 \%, w_{\mathrm{Si}} \leq 0.35 \%, w_{\mathrm{Mn}} \leq 0.75 \%\right.$, $w_{\mathrm{P}} \leq 0.010 \%, w_{\mathrm{Cr}} \leq 0.20 \%, w_{\mathrm{Ni}} \leq 0.25 \%, w_{\mathrm{Mo}} \leq 0.15 \%$, $w_{\mathrm{Cu}} \leq 0.20 \%$ ). The combination of diffusible deoxidation and precipitation deoxidation integrated process was adopted to ensure the purity and good fluidity of molten steel. Tapping temperature was in the range of 1650 to $1680{ }^{\circ} \mathrm{C}$. It is strictly prohibited for the oxidizing slag to enter into the refining package.

\section{LF ladle refining}

Chemical compositions of molten steel should be controlled strictly as shown in Table $1\left(w_{s} \leq 0.010 \%\right)$. During the process of refining, argon flowed smoothly, the molten steel was not exposed, the charging materials were baked well, and the diffusion deoxidizer was dry. The alloy con- 
tent was adjusted when the temperature reached between 1580 and $1590{ }^{\circ} \mathrm{C}$. Per one tonne of steel, $1 \mathrm{~kg}$ of carbon powder as diffusion deoxidizer and $2-3 \mathrm{~kg}$ of Si-Al-Ca-Ba powder were poured into the steel to ensure the reducing atmosphere. After the adjustment of alloy composition, refining white slag was held for more than 20 minutes, a right amount of diffusion deoxidizer was allowed to be added, but slag charge was prohibited. One kilogram of La was added to one tonne of the molten steel. The raised casting ladle temperature of the molten steel was $1540-1560{ }^{\circ} \mathrm{C}$ and pouring temperature was between 1530 and $1550{ }^{\circ} \mathrm{C}$.

The samples were normalized at $900{ }^{\circ} \mathrm{C}$ for 10 hours, and then air cooled, and tempered at $600{ }^{\circ} \mathrm{C}$ for 7 hours, followed by air cooling after cooling. Five samples were cut from accompanying specimens for tensile and impact tests, respectively. Mechanical properties were measured by means of an electronic tensile testing machine Shimadzu AG-I 250kN and impact tester Beijing United Test JB-30A. The microstructure and fracture morphology of the ASTM A216 steel was analysed by scanning electron microscope JSM-5610LV. The content of the added La was determined by energy-dispersive spectroscopy (EDS).

\section{Results and discussion}

\subsection{Effect of La on modification of inclusions}

After refining, most of the inclusions in the ASTM A216 steel were irregular, granular, and globular. However, there was still a small amount of strip inclusions. Fig. 1 shows the morphologies and EDS results of the typical inclusions in the ASTM A216 steel before and after modification. The EDS analysis in Fig. $1 \mathrm{~b}$ shows that the long strips of inclusions separated in the form of eutectic structure of Fe and MnS, existed along the grain boundary, and the length was greater than $20 \mu \mathrm{m}$ (without rare earth). The long strip inclusions had the characteristics of aggregation. After modification, the amount of inclusions decreased, and the morphologies of inclusions changed to globular from irregular mass and strip. As EDS analysis showed, the inclusions diffused in the dimples were lanthanum-sulfur compounds, and MnS inclusions adsorbed in its surrounding. The size of globular inclusions compositing with rare earth was less than $5 \mu \mathrm{m}$, and the long strip sulfide inclusions disappeared.

By the thermodynamic calculation, ${ }^{10,11}$ after adding La, the first to form were lanthanum oxides, followed by oxosulfides, and lastly lanthanum sulfides, caused by a strong affinity between lanthanum and oxygen and sulfur. Therefore, La has the desulfurization effect only after deoxidation. In the process of smelting, the oxygen content in the molten steel was low when La was added after refining deoxidation. Thus, LaS formed in the steel. The addition of La could inhibit the combination of manganese and sulfur, reduce long strips of $\mathrm{MnS}$ inclusions, form diffuse distribution of spherical rare earth compound inclusions, and improve the morphology and distribution of inclusions. Rare earth atoms could replace $\mathrm{Mn}$ and form a solid solution with $\mathrm{MnS}^{12}$ while the bonding force of covalent bonds with $\mathrm{S}$ was stronger than $\mathrm{Mn}$ with $\mathrm{S}$. In addition, the (Mn,La)S compound formed after solid solution of rare earth could increase the resistance to deformation capacity.
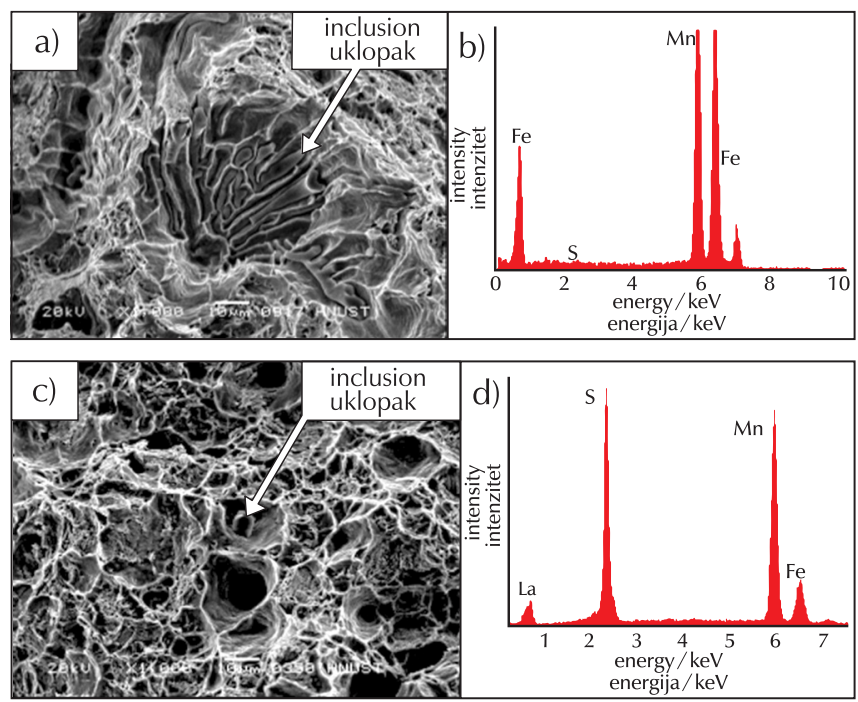

Fig. 1 - SEM fractographs of the ASTM A216 steel and EDS results for indicated: a) and b) without modificator; c) and d) with lanthanum

Slika 1 - SEM prijelomne površine i EDS čelika ASTM A216: a) i b) čelik bez modifikatora, c) i d) čelik s lantanom

\subsection{Effects of La on the microstructure and mechanical properties}

As shown in Fig. 2, the grain was refined significantly when La was added. Lanthanum exists in the form of rare earth inclusions, rare earth compounds, and solid solution in steels. ${ }^{7}$ Rare earth elements can completely dis-

Table 1 - Chemical composition of ASTM A216 steel

Tablica 1 - Kemijski sastav čelika ASTM A216

\begin{tabular}{|c|c|c|c|c|c|c|c|c|c|}
\hline \multicolumn{10}{|c|}{$w / \%$} \\
\hline $\mathrm{C}$ & Si & $\mathrm{Mn}$ & $\mathrm{P}$ & $\mathrm{S}$ & $\mathrm{Cr}$ & $\mathrm{Ni}$ & Mo & $\mathrm{Cu}$ & V \\
\hline $0.24-0.28$ & $0.30-0.45$ & $0.75-0.90$ & 0.015 & 0.010 & 0.20 & 0.25 & 0.15 & 0.20 & 0.03 \\
\hline
\end{tabular}

NotelNapomena: $w_{\mathrm{Cr}}+w_{\mathrm{Ni}}+w_{\mathrm{Mo}}+w_{\mathrm{Cu}}+w_{\mathrm{V}} \leq 1 \%$ 
solve in molten steel, and the solid solubility in the solid iron is low $(<10 \mathrm{ppm})$. The atomic radius of $\mathrm{La}$ and $\mathrm{Fe}$ is $0.1877 \mathrm{~nm}$ and $0.1210 \mathrm{~nm}$, respectively. The atomic radius of La is $50 \%$ larger than radius of Fe atom. ${ }^{13}$ During the solidification process, once the solid phase precipitated in the molten steel, the residual La enriched at the front of the crystallization, and formed an adsorption film near the grain boundary to prevent iron atoms from passing through. Meanwhile, the stability of the crystal nucleus could be improved. Finally, the size of grains was refined. With the reduction of the solidification temperature, the degree of supercooling was increased and the critical nucleation of the crystal nucleus size became smaller. When it reached a certain degree, the entire volume could nucleate to an isometric crystal. In addition, La could further refine grains caused by surface-active effects of La, reduce the surface tension of the molten steel, and improve the grain nucleation rate.

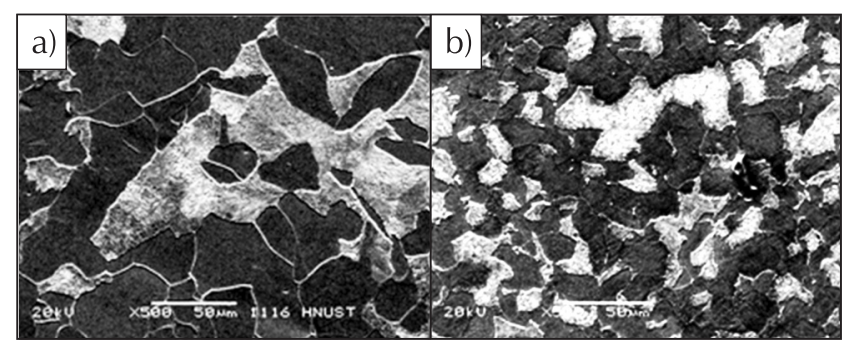

Fig. 2 - Microstructures of ASTM A216 steel: a) without lanthanum; b) $w_{\mathrm{La}}=0.1 \%$

Slika 2 - Mikrostruktura čelika ASTM A216: a) bez lantana, b) $w_{\text {La }}$ $=0.1 \%$

The experimental molten steel was well deoxidized when a certain amount of La was added. A small amount of La was consumed by residual oxygen in the steel to form $\mathrm{La}_{2} \mathrm{O}_{3}$, and the rest reacted with $\mathrm{S}$ to generate LaS, which oxidized as rare earth oxosulfide $\left(\mathrm{La}_{2} \mathrm{O}_{2} \mathrm{~S}\right)$ during the following process of casting. Considering the angle difference of the two lattices, B. L. Bramfitt ${ }^{14}$ proposed the theory of a two-dimensional lattice misfit after many experiments and calculations, which was defined as:

$$
\delta_{(h k l)_{n}}^{(h k l) s}=\frac{1}{3} \sum_{i=1}^{3} \frac{\left|d_{[u v w]_{s}^{i}} \cos \theta-d_{[u v w]_{n}^{i}}\right|}{d_{[u v w]_{n}^{i}}}
$$

where $(h k l)_{\mathrm{s}}$ and [uvw] $]_{\mathrm{s}}$ are low-index plane of the substrate and its low-index direction respectively; $(h k l)_{n}$ and $[u v w]_{n}$ are low-index plane in the nucleated solid phase and its low-index direction, respectively; $d[u v w]_{n}$ and $d[u v w]_{s}$ are the interatomic spacing along $[u v w]_{n}$ and $[u v w]_{s}$, respectively; $\theta$ is the angle between the $[u v w]_{\mathrm{S}}$ and $[u v w]_{\mathrm{n}}$.

During the process of non-spontaneous nucleation, the smaller the $\delta$ value, the better the match between the two phases, and the easier the solid phase particles could be a non-spontaneous crystallization core. When the value of $\delta$ is between $6 \%$ and $12 \%$, the solid phase particle can be the non-spontaneous crystallization core, and when the value of $\delta$ is less than $6 \%$, non-spontaneous crystallization becomes the easiest. However, when the value of $\delta$ is more than $12 \%$, the non-spontaneous crystallization cannot occur.

$\mathrm{La}_{2} \mathrm{O}_{3}$ has a close-packed hexagonal structure, the lattice parameters $\left(1500{ }^{\circ} \mathrm{C}\right)$ are: $a_{0}=0.40184 \mathrm{~nm}$, $C_{0}=0.61361 \mathrm{~nm}$. $\delta$-Iron has a cubic structure, and the lattice parameter is $a_{0}=0.29369 \mathrm{~nm}$. The crystal orientations and calculations of the mismatch degree between each crystal face are shown in Fig. 3 and Table 2, respectively. Table 2 suggests that the mismatch degree between the crystal face (111) of $\delta$-Fe and the crystal face (0001) of $\mathrm{La}_{2} \mathrm{O}_{3}$ is $3.34 \%$, and thus $\mathrm{La}_{2} \mathrm{O}_{3}$ can be the effective core for the nucleation of $\delta$-Fe.

$\mathrm{La}_{2} \mathrm{O}_{2} \mathrm{~S}$ is of hexagonal crystal structure and the lattice parameter is $\mathrm{a}_{0}=0.4051 \mathrm{~nm},(0001) \mathrm{La}_{2} \mathrm{O}_{2} \mathrm{~S} \|$ (111) $\delta$-Fe; The face of LaS is of centered cubic structure and the lattice parameter is $a_{0}=0.5843 \mathrm{~nm},(111) \mathrm{LaS} \|(111)$ $\delta$-Fe. The crystal orientations between $\mathrm{La}_{2} \mathrm{O}_{2} \mathrm{~S}$ and $\delta$-Fe, LaS, and $\delta$-Fe are shown in Fig. 4. The mismatch degrees are $2.6 \%$ and $0.6 \%$, respectively, which indicates that both $\mathrm{La}_{2} \mathrm{O}_{2} \mathrm{~S}$ and LaS can be non-spontaneous crystallization cores for $\delta$-Fe.

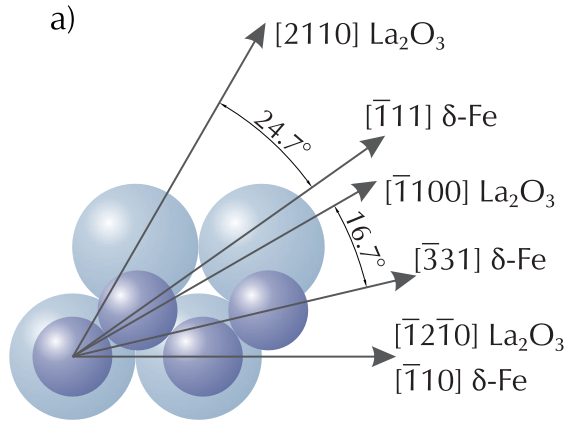

(0001) $\mathrm{La}_{2} \mathrm{O}_{3} \|(110) \delta-\mathrm{Fe}$

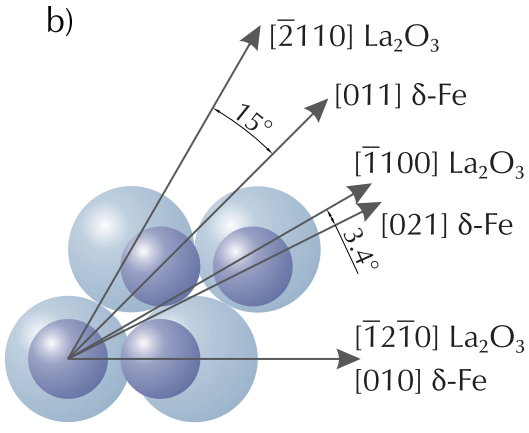

(0001) $\mathrm{La}_{2} \mathrm{O}_{3} \|(100) \delta-\mathrm{Fe}$

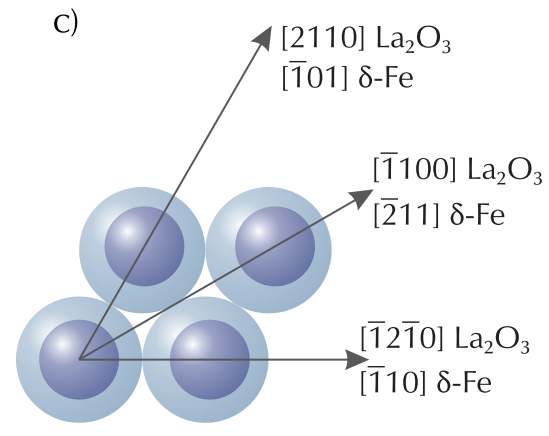

(0001) $\mathrm{La}_{2} \mathrm{O}_{3} \|(111) \delta-\mathrm{Fe}$

Fig. 3 - Orientation of lattice planes of $\mathrm{La}_{2} \mathrm{O}_{3}$ to $\delta$-iron Slika 3 - Orijentacija mrežnih ravnina $\mathrm{La}_{2} \mathrm{O}_{3}$ i $\delta$-željeza 
14 A.-Q. WANG et al.: Effect of Lanthanum on Microstructures and Properties of ASTM A216 Steel, Kem. Ind. 65 (1-2) (2016) 11-16

Table 2 - Calculations of mismatch degree between $\mathrm{La}_{2} \mathrm{O}_{3}$ and $\delta$-iron

Tablica 2 - Podudaranje kristalnih struktura $\mathrm{La}_{2} \mathrm{O}_{3}$ i $\delta$-željeza

\begin{tabular}{|c|c|c|c|c|c|c|c|c|c|}
\hline \multirow{4}{*}{$\begin{array}{c}{[u v w] \mathrm{La}_{2} \mathrm{O}_{3}} \\
{[u v w l] \delta-\mathrm{Fe}}\end{array}$} & \multicolumn{9}{|c|}{$\begin{array}{l}\text { Matching lattice planes } \\
\text { Podudarne mrežne ravnine }\end{array}$} \\
\hline & \multicolumn{3}{|c|}{ (0001) $\mathrm{La}_{2} \mathrm{O}_{3} \|(110) \delta$-Fe } & \multicolumn{3}{|c|}{ (0001) $\mathrm{La}_{2} \mathrm{O}_{3} \|(100) \delta-\mathrm{Fe}$} & \multicolumn{3}{|c|}{ (0001) $\mathrm{La}_{2} \mathrm{O}_{3} \|(111) \delta-\mathrm{Fe}$} \\
\hline & {$[2110]$} & {$[1100]$} & {$[\overline{1} 2 \overline{1} 0]$} & {$[2110]$} & {$[\overline{1} 100]$} & {$[\overline{1} 2 \overline{1} 0]$} & {$[2110]$} & {$[\overline{1} 100]$} & {$[\overline{1} 2 \overline{1} 0]$} \\
\hline & {$[\overline{1} 11]$} & {$[\overline{3} 31]$} & {$[\overline{1} 10]$} & [011] & [021] & [010] & [101] & {$[\overline{2} 11]$} & {$[\overline{1} 10]$} \\
\hline$d_{\text {[urw] }}\left(\mathrm{La}_{2} \mathrm{O}_{3}\right) / \mathrm{nm}$ & 0.4018 & 0.6960 & 0.4018 & 0.4018 & 0.6960 & 0.4018 & 0.4018 & 0.6960 & 0.4018 \\
\hline$d_{[\text {unw] }}(\delta-\mathrm{Fe}) / \mathrm{nm}$ & 0.2546 & 0.6407 & 0.4157 & 0.4157 & 0.6573 & 0.2940 & 0.4157 & 0.7201 & 0.4157 \\
\hline$\theta /^{\circ}$ & 24.7 & 16.7 & 0 & 15 & 3.4 & 0 & 0 & 0 & 0 \\
\hline$\delta / \%$ & & 17.2 & & & 16.3 & & & 3.34 & \\
\hline
\end{tabular}

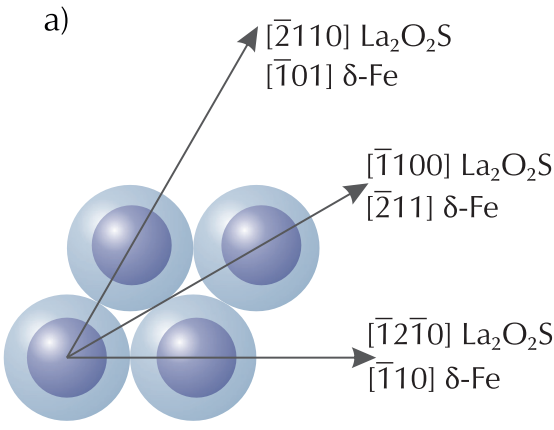

(0001) $\mathrm{La}_{2} \mathrm{O}_{2} \mathrm{~S} \|(111) \delta-\mathrm{Fe}$

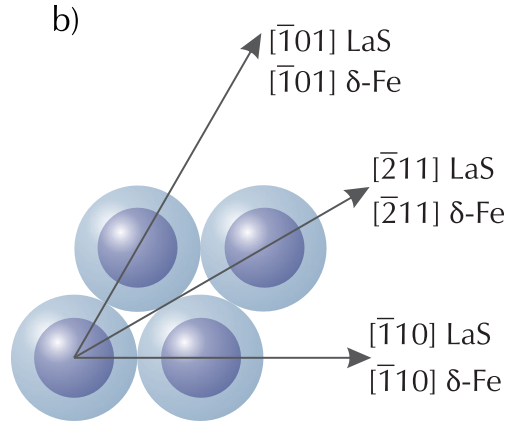

(111) LaS || (111) $\delta$-Fe

Fig. 4 - Orientation of lattice planes of $\mathrm{La}_{2} \mathrm{O}_{2} \mathrm{~S}$ and $\mathrm{LaS}$ to $\delta$-iron

Slika 4 - Orijentacija mrežnih ravnina $\mathrm{La}_{2} \mathrm{O}_{2} \mathrm{~S}$ i LaS prema $\delta$-željezu

Table 3 - The mechanical properties of ASTM A216 steel Tablica 3 - Mehanička svojstva čelika ASTM A216

\begin{tabular}{|c|c|c|c|c|}
\hline $\begin{array}{c}\text { Samples } \\
\text { Uzorci }\end{array}$ & 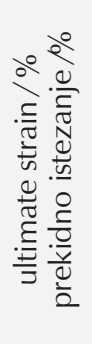 & 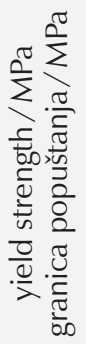 & 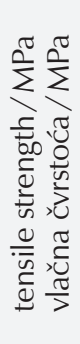 & 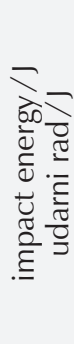 \\
\hline $\begin{array}{c}\text { without La } \\
\text { bez La }\end{array}$ & 27 & 293 & 477 & 49 \\
\hline$W_{\mathrm{La}}=0.1 \%$ & 31 & 346 & 536 & 58 \\
\hline
\end{tabular}

The mechanical properties of materials with and without La are shown in Table 3. It clearly reveals that the addition of La can significantly improve the mechanical properties of materials. Before modification, a part of inclusions were strip and distributed collectively along the grain boundary, hence the uniform continuity of the steel substrate was damaged and the concentration of stress occurred. Under the action of external force, microcracks nucleate, grow, and extend on the inclusions firstly, which leads to the fracture and low mechanical properties of the materials. ${ }^{15-18}$ The addition of La could control the morphologies of inclusions and improve the formation of dispersed globular inclusions, eliminate strip inclusions distributed collectively along the grain boundary. In addition, it can improve the resistances of inclusion and grain boundary to crack initiation and propagation. The dimples became more and deeper, which obviously demonstrated that the addition of La could reduce the tendency of brittle fractures along the grain boundary. This indicated an increase in impact toughness.

The La in the solid solution of steel had improved the condensate depression of the ASTM A216 melt, which could not only refine the microstructures of ASTM A216 steel, but also cause many inclusions to nucleate abruptly and decrease in size. All the rare earth compounds, like $\mathrm{La}_{2} \mathrm{O}_{3}$, $\mathrm{La}_{2} \mathrm{O}_{2} \mathrm{~S}$, and LaS, formed by the reaction between $\mathrm{La}$ and steel liquid or air, are good non-spontaneous nucleation cores of $\delta$-Fe. They can further refine the crystalline grain of ASTM A216 steel and decrease the space of pearlite pieces. Therefore, the mechanical properties of steel could be improved significantly. 


\section{Conclusions}

By the addition of La, good mechanical properties of castings were obtained due to refined microstructure and morphology change of inclusions in ASTM A216 steel. The morphology of inclusions changed from strip MnS to globular rare earth compound inclusions. The refined microstructure was caused by the synergistic effect of the enhanced condensate depression of molten steel and lanthanum compounds $\left(\mathrm{La}_{2} \mathrm{O}_{3}, \mathrm{La}_{2} \mathrm{O}_{2} \mathrm{~S}\right.$ and $\left.\mathrm{LaS}\right)$ as a non-spontaneous nucleation core. The lanthanum compounds formed in the molten steel are good non-spontaneous nucleation cores of $\delta$-Fe.

\section{List of abbreviations and symbols Popis kratica i simbola}

\begin{tabular}{|c|c|}
\hline$a, c$ & $\begin{array}{l}\text { - lattice parameters } \\
\text { - parametri kristalne rešetke }\end{array}$ \\
\hline EDS & $\begin{array}{l}\text { - energy-dispersive X-ray spectroscopy } \\
\text { - energijski disperzivna rendgenska spektroskopija }\end{array}$ \\
\hline$d[u v w]$ & $\begin{array}{l}\text { - interatomic spacing along direction }[u v w] \\
\text { - međuatomska udaljenost u smjeru }[u v w]\end{array}$ \\
\hline$(h k l)$ & $\begin{array}{l}\text { - Miller indices of lattice plane } \\
\text { - Millerovi indeksi mrežne ravnine }\end{array}$ \\
\hline LF & $\begin{array}{l}\text { - ladle furnace } \\
\text { - lončasta peć }\end{array}$ \\
\hline$n$ & $\begin{array}{l}\text { - nucleus } \\
\text { - nukleus }\end{array}$ \\
\hline S & $\begin{array}{l}\text { - supstrate } \\
\text { - podloga }\end{array}$ \\
\hline SEM & $\begin{array}{l}\text { - scanning electron microscope } \\
\text { - pretražni elektronski mikroskop }\end{array}$ \\
\hline$[u v w]$ & $\begin{array}{l}\text { - Miller indices of direction } \\
\text { - Millerovi indeksi smjera }\end{array}$ \\
\hline w & $\begin{array}{l}\text { - mass fraction, } \% \\
\text { - maseni udjel, } \%\end{array}$ \\
\hline$\delta$ & $\begin{array}{l}\text { - crystall structure mismatch degree } \\
\text { - stupanj podudaranja kristalnih struktura }\end{array}$ \\
\hline$\theta$ & $\begin{array}{l}\text { - angle between the crystallographic directions } \\
\text { - kut među kristalografskim smjerovima }\end{array}$ \\
\hline
\end{tabular}

\section{References \\ Literatura}

1. K. D. Xu, L. J. Xiao, Deoxidation and inclusion control in special steel refining, Iron and Steel 47(10) (2012) 1-13.

2. H. M. Zhang, C. Y. Cui, L. P. Zhao, L. F. Wu, D. C. Feng, Effects on Corrosion Resistance and Mechanical Property of Lanthanum-Contained 4Cr13 Steel, J. Chinese Soc. Rare Earth. 29(1) (2011) 100-104.
3. X. Z. Jiang, B. F. Wang, C. L. Li, Impact of La on Inclusions and Corrosion Resistance of Pure Steel, Rare Metals and Cemented Carbides 33(4) (2005) 28-31.

4. L. M. Wang, Application Prospects and Behavior of RE in New Generation High Strength Steels with Superior Toughness, J. Chinese Soc. Rare Earth. 22(1) (2004) 48-54.

5. C. L. Li, New development of Research and Application of Rare Earth on steels, Chinese Rare Earths 34(3) (2013) 79-85.

6. L. M. Wang, Q. Lin, L. J. Yue, Study of application of rare earth elements in advanced low alloy steels, J. Alloy. Compd. 451 (2008) 534-537, doi: http://dx.doi.org/10.1016/j.jallcom.2007.04.234

7. L. J. Yue, L. M. Wang, J. S. Han, Effects of rare earth on inclusions and corrosion resistance of 10PCuRE weathering steel, J. Rare Earth. 28(6) (2010) 952-956, doi: http://dx.doi. org/10.1016/S1002-0721(09)60219-2.

8. Q. Lin, F. Guo, X. Y. Zhu, Behaviors of Lanthanum and Cerium on Grain Boundaries in Carbon Manganese Clean Steel, J. Rare Earth. 25(4) (2007) 485-489, doi: http://dx.doi. org/10.1016/S1002-0721(07)60461-X.

9. F. Guo, Q. Lin, Existing Forms of Lanthanum in Purity Steels, J. Rare Earth. 24(S1) (2006) 405-408, doi: http://dx.doi. org/10.1016/S1002-0721(07)60413-X.

10. F. Guo, Q. Lin, X. Y. Shun, Thermodynamic Calculation on Precipitation and Transformation of Inclusions in High Purity Carbon-Manganese Steels with Rare Earths and Their Microstructure Analysis, J. Chinese Soc. Rare Earth. 22(5) (2004) 614-618.

11. A. X. Sha, F. M. Wang, C. J. Wu, L. R. Dong, S. Y. Li, Y. X. Chen, L. X. Zhu, Fixation of Tramp Elements in Steel by Lanthanum, Chinese J. Rare Metals 24(4) (2000) 287-291.

12. S. B. Wang, J. J. Li, S. C. Yin, H. R. Ren, B. S. Xu, Effect of micro-RE element on microstructures and mechanical properties of Q235B steel, Mater. Sci. Tech. 19(5) (2011) 79-89.

13. F. Li, H. P. Ren, Z. C. Liu, C. L. Li, Q. Wang, Influence of La on microstructure of purity steel, J. Baotou Univ. Iron Steel Tech. 23(2) (2005) 144-147.

14. N. Pan, B. Shong, Q. J. Zai, B. Wen, Effect of lattice disregistry on the heterogeneous nucleation catalysis of liquid steel, J. Univ. Sci. Tech. Beijing 32(2) (2010) 179-182.

15. D. H. Chen, Q. Lin, F. Guo, P. X. Gao, Y. H. Wang, H. Y. Wan, Effect of High La Rare Earth Additives on Properties of $16 \mathrm{Mn}$ Steel, J. Univ. Sci. Tech. Beijing 26(6) (2004) 600-603.

16. F. Zhang, J. C. Yang, Y. H. Liu, Effect of Lanthanum on Microstructures and Mechanical Properties of SS400 Steel, J. Chinese Soc. Rare Earth. 26(6) (2008) 728-743.

17. M. G. J. Warren, L. M. James, Lanthanum additions and the toughness of ultra-high strength steels and the determination of appropriate lanthanum additions, Mater. Sci. Eng. A 403 (2005) 299-310, doi: http://dx.doi.org/10.1016/j. msea.2005.05.021.

18. L. Qi, A. M. Zhao, Z. Z. Zhao, Effect of rare earth La addition on microstructures and properties of $\mathrm{Nb}$-Ti-Mo pipeline steel, Trans. Mater. Heat Treat. 33(12) (2012) 82-87. 


\section{SAŽETAK}

\section{Utjecaj lantana na mikrostrukturu i svojstva čelika ASTM A216 \\ Aiqin Wang, ${ }^{\mathrm{a}^{*}}$ Ming Li, ${ }^{\mathrm{a}}$ Douqin Ma, ${ }^{\mathrm{b}}$ Qinjie Wu ${ }^{\mathrm{b}} \mathrm{i}$ Jingpei Xie ${ }^{\mathrm{a}}$}

Da bi se zadovoljili standardi Međunarodnog udruženja klasifikacijskih zavoda (IACS) za lijevanje krmenog roga, potrebno je poboljšati svojstva čelika ASTM A216. Odljevci krmenog roda i prateći uzorci, nakon taljenja čelika u elektrolučnoj peći, rafiniranja i dodatka lantana, izrađeni su lijevanjem čelika u kalupe. Uzorci su prvo normalizirani zagrijavanjem 10 sati na $900{ }^{\circ} \mathrm{C}$, ohlađeni na zraku, potom podvrgnuti popuštanju 7 sati na $600{ }^{\circ} \mathrm{C}$ i ponovno ohlađeni na zraku. Određena su mehanička svojstva uzoraka i proučena mikrostruktura. Analizirana je sličnost kristalne građe spojeva lantana nastalih u rastaljenom čeliku i $\delta$-željeza. Izračunata je učinkovitost lantanovih spojeva kao podloge za heterogenu nukleaciju $\delta$-željeza na temelju dvodimenzijskog nepodudaranja struktura. Dodatkom lantana vrpčasti uklopci MnS postaju zrnasti uklopci spoja rijetke zemlje. Finija mikrostruktura dobivena je sinergijskim djelovanjem povećane depresije kondenzata i brže nukleacije uz lantan.

Ključne riječi

Čelik ASTM A216, uklopak, lantan, dvodimenzijsko nepodudaranje, profinjenje zrna

a School of Materials Science and Engineering, Henan University of Science and Technology, 471023 Luoyang, Kina

${ }^{\mathrm{b}}$ School of Physical Engineering, Zhengzhou University, 450001 Zhengzhou, Henan, Kina
Izvorni znanstveni rad Prispjelo 23. studenoga 2015. Prihvaćeno 28. prosinca 2015. 